UDC $811.163 .41 ' 342.8$

https://doi.org/10.18485/ms_zmsfil.2020.63.1.9

Изворни научни рад

\title{
Мирјана Петровић-Савић
}

\section{О ТРАГОВИМА НЕОАКУТА У ГОВОРИМА СЕВЕРОЗАПАДНЕ СРБИЈЕ}

У овом раду саопштићемо прве резултате наших истраживања о постојању неоакута на терену северозападне Србије (Јадар, Рађевина, Подгорина, Колубара и Посавотамнава). Грађа, којом овом приликом располажемо, показује да се овај стари акценат

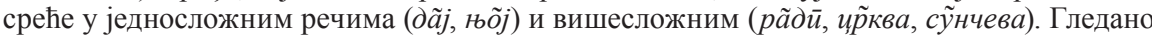
по врстама речи, забележили смо га код глагола, именица, заменица, придева и прилога.

Кључне речи: дијалектологија, неоакут, дугоузлазни акценат, северозападна Србија, Колубара, Подгорина, Рађевина, Јадар, Посавотамнава.

In this paper, we offer the first results of our research on the existence of the neoaccute accent in the territory of northwest Serbia (Jadar, Rađevina, Podgorina, Kolubara i Posavotamnava). The materials available to us for this study show that this old accent is encountered

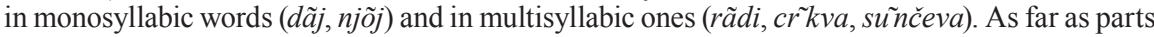
of speech are concerned, it can be found in verbs, nouns, pronouns, adjectives, and adverbs.

Key words: dialectology, neoaccute accent, long falling accent, northwestern Serbia, Kolubara, Podgorina, Rađevina, Jadar, Posavotamnava.

Област северозападне Србије (Јадар, Рађевина, Подгорина, Колубара и Посавотамнава) јесте област из које имамо неколико општих дијалектолошких описа (в. Николић 1966; 1968; 1969; Реметић 1981; Reметіс́ - Ivić 1981; ПЕтровић 2005; РАдовАновић 2006; 2014), али и поред тога у овоме ареалу могу искрснути нова, занимљива питања, ${ }^{1}$ при чему ту спада и прецизније утврђивање изоглосе неке од језичких појава. Свакако највећу пажњу домаће науке привукло је откриће незамењенога јата и објашњење његовога порекла (в. РЕметић 1981; 1981a), чиме је једна „типична” говорна зона шумадијско-војвођанског дијалекта осветљена из историјског угла пре крупних миграција које су темељно измениле говорну слику овога подручја. Међутим, један од приоритета српске дијалектологије јесте и утврђивање граница неоакута, а наше истраживање на терену показује присуство, у траговима, и ове друге значајне предмиграцијске црте. Стога циљ овога рада и јесте регистровање појаве на доста широком простору, који смо прелиминарно омеђили својим истраживањима. У будућем раду намера нам је оцртавање границе овом архаизму на терену (северо)западне Србије, с нарочитим освртом на подударање с границом незамењенога јата, будући да је већ назначено да се „акут у говорима северне и западне Србије могао укрштати и са исто тако архаичним чувањем фонолошке индивидуалности јата" (Петровић - Гудурић 2008: 419).

${ }^{1}$ О степену испитаности шумадијско-војвођанског дијалекта, као и говора у овом делу северозападне Србије, в. РАдовановић - БошњАковић 2009. 
У српској историјској акцентологији сматрало се да је у источном и јужном делу штокавских говора, тј. на српском етничком простору, прасловенски неоакут нестао из акценатског система око VII-VIII века (БЕлић 1958: 6). Међутим, пре нешто више од четврт века, Павле Ивић је у студији Неоакуй на йадинама Койаонка утврдио фонолошки статус овој појави, за коју наводи да представља заједничку научну својину његову и С. Реметића (1994: 241), износећи запажање ,да у области источно и североисточно од Копаоника постоји ареал дуг најмање 40 километара у ваздушној линији у којем неоакут није изједначен са дугим силазним акцентом. На северу тај ареал допире готово до саме Западне Мораве на сектору између Трстеника и Крушевца, а на југу он се простире бар до Мерћеза и Мрча западно од Куршумлије” (Ивић 1994: 245). У истом раду закључено је да ,језгро србијанског ареала чувања акута чини по свој прилици Александровачка жупа, где је тај акценат веома жив и у једносложницама, па и на ултими вишесложница" (Ивић 1994: 246). Овај акценат је потом потврђен у лепосавићкој околини (РАдоичић 1996), проучени су његови трагови у студеничким говорима (ДРАгин 2005), као и његово постојање у траговима на падинама самог Копаоника, у говорима Косова и Метохије (РАдић 2010а). ${ }^{3}$ На чињеницу да је дугоузлазни акценат на месту дугосилазног познат и у говору јагодинског краја, скреће пажњу Првослав Радић (2004: 255). Драгољуб Петровић и Снежана Гудурић 2008. године на северном подножју Рудника бележе „више примера са ‘необичним’ дугоузлазним акцентом у неким типовима примера, пре свега у једносложним прилошким облицима типа но́д, во́д, г̇óp, до́л и у

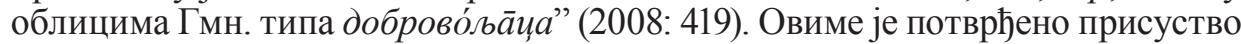
старог акцента на новоштокавском, четвороакценатском терену. У прилогу

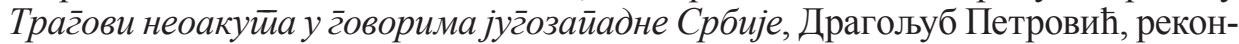
струишући предмиграциону дијалекатску слику на простору од Драгачева до северног подножја Рудника као косовско-ресавску, наглашава да би додатна истраживања на том простору требало да покажу „да ли су јужне падине Повлена и Маљена могле бити она линија до које је тај дијалекатски масив према северу имао најдаљи домашај или се ‘зауставио' негде на међи југоисточне зоне Ужичке Црне горе и таковскога краја” (2010: 400). Да то није најсевернија тачка чувања неоакута, помишља Виктор Савић уприлогу из историјске акцентуације, у којем ради одгонетања система надредних знакова у једном историјском споменику користи резултате својих теренских истраживања (1998; 2001) у области Ваљевске Подгорине, где је у једносложним облицима слушао 'необичан' дугоузлазни акценат на позицији неоакута или пак са секундарном реализацијом тамо где је обичан дугоузлазни акценат неодржив (САвич 2019: 342). ${ }^{4}$ У новијим дијалектолошким студијама с овога терена (РАдовАновић 2006; 2014), поменута појава није примећена.

\footnotetext{
${ }^{2}$ Првослав Радић је, пишући о говору села Мрче у куршумлијском крају, запазио ,један нетипичан дуги узлазни акценат” и као главно наметнуло му се питање ,да ли се овај акценат може довести у везу са метатонијским акутом" (1990: 9). У самом раду, примере са овим нетипичним дугоузлазним акцентом бележио је знаком за акут ( ).

${ }^{3}$ Софија Милорадовић љубазно нам је дала на увид рад, који се налази у штампи, у којем скреће пажњу на значај те особине у косовско-ресавским говорима (МилорАдовић 2019).

${ }^{4}$ Појава је илустрована примерима: њо̃ј, но̃д, во̃д; зала́дй, жу́рӣм (САвич 2019: 342). Аутор износи претпоставку да се на простору данашње централне Србије, од Западне Мораве, па све
} 
Овим радом настојимо засигурно померити границу дугог акута у овом делу западне Србије: и северније и западније у односу на ону до које је у својим истраживањима дошао Драгољуб Петровић. Корпус за потребе овог истраживања представља расположива грађа из Јадра, Рађевине, Подгорине, Колубаре и Посавотамнаве. ${ }^{5}$ Овај рад је, првобитно, замишљен као испитивање постојања неоакута на терену Рађевине. Пре петнаестак година објављен је рад Основне фонейске особине г̄овора рађевског̄ села Беле Цркве (Петровић 2005). Приликом израде тога прилога, приметили смо присуство дугоузлазног акцента на једносложним прилозима типа $\bar{u} y ́$, но́ , до́л, где му, са становишта акценатске теорије, није место. Пошавши од раширеног уверења у нашој струци да су те једносложнице резултат губљења целога постакценатског слога ( $\bar{w} y$, ум. $\bar{w} y \partial е$ и сл.), овој појави нисмо придали одговарајући значај. Постојање тога акцента у поменутој позицији и даље је представљало начелни проблем у реализацији дугоузлазног акцента који из историјских и интонационих разлога изискује, по моделу, постојање најмање два везана слога, од којих је други неакцентован. Када је неоакут потврђен на обронцима Рудника (ПЕтровић - Гудурић 2008), оживела је и наша пређашња идеја о његовом постојању у Рађевини. Поновним преслушавањем трака из Рађевине, сада с другим циљем, овај необичан акценат најпре смо чули у Липеновићу (зна̃ч $\bar{u})$. У том селу, код истог информатора, бележили смо дати акценат у почетку само код овог глагола. Када је, касније, сам информатор проширио репертоар примера с оваквим акцентом, одагнали смо сумњу да је реч о лексикализованој појави. Према нашем материјалу, који овде није у целости наведен, ${ }^{6}$ испоставило се да неоакута има на целој територији Рађевине. С друге стране, сазнање да је неоакут забележен и на Руднику, навело нас је на то да циљано проширимо ареал свога истраживања. Најпре смо преслушали траке из пунктова које смо током 2005. године посетили за потребе

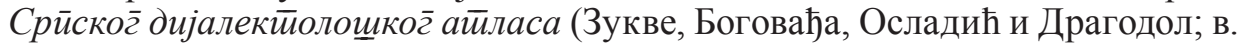
нап. 7). Касније, сакупљајући ономастичку грађу на терену Јадра, искористили смо прилику да проверимо да ли је и на том терену присутна ова појава. На основу наших аудио-записа, праћена појава потврђена је у оном делу Јадра из којег имамо материјал. Након тога, ради убирања контролних пунктова, дошли смо до грађе и из још неких подгорских села (Царина, Гуњаци, Остружањ и село Осечина). Испоставило се да смо у свакоме од њих слушали дугоузлазни акценат на месту где се очекује дугосилазни, тј. на месту старог акута, односно - да у свакоме од њих имамо трагове неоакута.

до Саве и Дунава на северу, у предмиграционом периоду формирао говорни тип који наслеђују данашњи шумадијско-војвођански и смедеревско-вршачки говори (САвич 2019: 342 ).

${ }^{5}$ Са по једним пунктом, заступљене су Посавотамнава и Колубара. У првој области посетили смо село Зукве, а у другој - Боговађу. И у једном и у другом пункту, као и у селима Драгодол и Осладић, која припадају Подгорини, и Липеновићу у Рађевини, грађу смо саку-

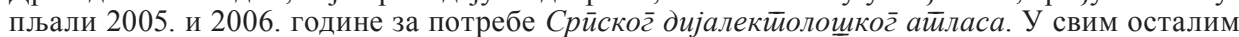
пунктовима који не припадају Рађевини, грађа је сакупљана у последњих неколико година. На терену Рађевине, у одређеним временским интервалима, грађу смо сакупљали од 2003. године до данас.

6 За сада, циљ нам није била исцрпност примера и њихова детаљна анализа, већ прелиминарно регистровање појаве на одређеном терену ради отварања могућности утврђивања њеног простирања. 
На посматраном терену, дуги акут, односно његови трагови, јавља се како у вишесложним речима тако и у једносложним. Забележене примере даћемо разврстане по категоријама речи у којима смо га бележили: глаголи, именице, заменице, придеви и прилози, држећи се азбучног реда потврда, италиком, иза којих у загради следи назив пункта. Акценат из техничких разлога бележимо знаком који је уобичајен у нашој дијалектологији ( $)$, на овоме месту без залажења у осетљиво питање његове акустичке вредности (в. ниже). Напомињемо да се већина наших примера реализује и с дугосилазним акцентом. ${ }^{7}$

1) У гллаг̄олским облицима неоакут смо бележили у презенту следећих глагола и то на првом слогу, одн. на глаголској основи. У грађи којом располажемо, немамо примера с овим акцентом на крајњем слогу, тј. на наставку:

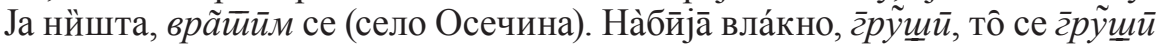
(Ставе). Гӓвран г̃ãye (Боговађа). До̃ђу нам ко̀мшйнке (Царина). Да̃j нёшто да пӧпијёмо (Ставе). И зна̃чи ето у̀спео̄ сам тоิ (Сипуља); Зна̃чй јёду сила́жу (Сипуља). Зйда се ци́гло̄м (Осладић); То зна̃чй поредовни́ци, моิј ре̂д је да̀на̄с (Липеновић). Штӓ то зна̃чй Бра̀им страิне (Липеновић). Ка̃ж) о̀ни мѐни (Ли-

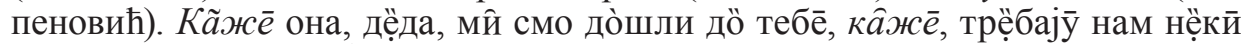
пода́ци (Липеновић). ${ }^{8}$ Ка̃же̄, ка̃же̄ знаิш ли тй дёда (Липеновић). Ка̃же̄, штӧ се тво̀је сѐло зо̀вё та̀ко̄ (Липеновић). Ма̃зйм, штӓ ћу (Бела Црква). Да и ра̃нимо, да и издрेжа̄вамо (село Осечина). Ше̂с гӧдйна како ра̃дй (Зукве). Рव̃̃u ја̀шт

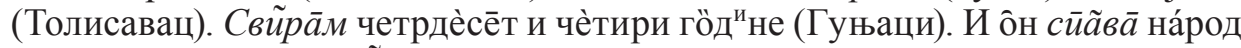

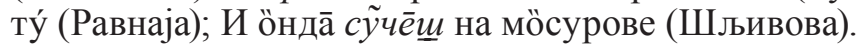

2) Код именица је овај акценат забележен у следећим примерима:

А ја̂ сам мла̃да (у значењу 'невеста') сто̀јйм ту̃ (Драгодол). Мо̀ја ма̃jка

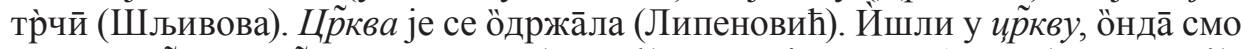

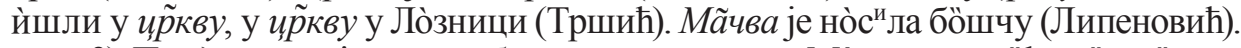

3) Придеви у којима смо бележили неоакут: Мо̀чила су вёће̄ рӱпе йско-

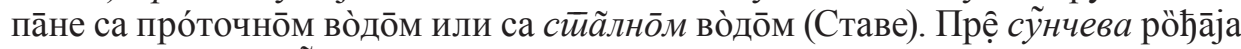
(Гуњаци). Јёсте зиимско̄, али млӓдо̄ст (Тршић).

4) Заменице са забележеним неоакутом: Узме̄ се престе̄н њо̃j (Шљивова). Ӧн је до̀шо о́вде (Бела Црква). Ва̃с две̣ трё̣ба̄ (Липеновић). Тãj швӓпскй во̀јнйк (Липеновић).

5) Прилози са забележеним неоакутом: Сто̀јӣм $\bar{u} \tilde{y}$ (Драгодол). Би́ла им кӱћа но̃д (Бела Црква). Во̃д су по̀падали (Комирић). Кад су би́ли но̀ма̄д, $\bar{u} \tilde{y}$ су доेшли (Бела Црква). Стӓви во̃д (Ставе).

Грађа коју смо представили у овом раду показала је да се неоакут на истраживаном терену бележи у готово истим категоријама речи у којима се бележи и у другим крајевима (уп. нпр. Ивић 1994: 243; Петровић - Гудурић 2008: 421; РАдић 2010а: 231): у облицима презента, код именица, придева, заменица и прилога. У нашим примерима, дуги акут је својом позицијом

\footnotetext{
${ }^{7}$ Има и изузетака: на пример, у селу Бела Црква у Рађевини искључиво смо слушали ма̃зи, ла̃дu; због чега и претпостављамо да таквих изузетака има још и да се могу срести и у другим пунктовима.

${ }^{8}$ У овом примеру, тј. реченици, јасно се види како један информатор наизменично користи дугосилазни акценат и акут.
} 
везан за први слог у речи, где конкурише дугосилазном акценту из новоштокавског, по пореклу источнохерцеговачког система. То значи да је његова реализација у начелу везана за коренски део речи, у граматичкој равни подударан с основом за облик код променљивих речи. Може се рећи да није ограничен број слогова од којих се речи с овим акцентом састоје, није ограничен (једносложне, двосложне, вишесложне).

Материјал којим располажемо сматрамо репрезентативним јер показуje, често, и врло типичне примере за акут, израније нам познате из литературе. Ипак, у овоме часу не располажемо подједнаком количином грађе из сваког пункта и пунктови нам нису равномерно распоређени по областима, што ћемо кориговати у предстојећим, систематским истраживањима овде оцртаног терена, па стога наводе изнете у овом прилогу сматрамо прелиминарним, тј. неком врстом најаве прецизнијег утврђивања правца простирања и ширине обухвата ове значајне фонетске црте. На пример, из Посавотамнаве располажемо подацима само за један пункт (Зукве), али потврда неоакута из овога места, једина у снимљеном материјалу, у исто време је типична за тај акценат ( $р \tilde{a} \partial \bar{u})$.

Примери предочени у овоме прилогу наводе нас на закључак да је на простору северозападне Србије дуги акут присутан, па макар и у траговима. Забележени и овде представљени примери потврђују његово постојање и доказ су да се он није сасвим изједначио с дугосилазним акцентом. Пошто се у свим другим позицијама јасно разликује дистрибуција дугоузлазног и дугосилазног акцента, очито је да у овим позицијама то не може бити обичан дугоузлазни, него мора бити стари акут. Акутски интонирани слог, према нашем слушном утиску, има подигнуту тонску линију, константнију од оне код дугоузлазног акцента, или прилично равну, с блажим падом на постакценатском слогу него код истога, дугоузлазног акцента; код једносложних речи могући је нагли скок мелодијске линије. У начелу, наведено одговара досадашњима описима истога акцента у јужнијим српским областима. ${ }^{9}$ У неким случајевима јасније смо чули ову посебну акценатску вредност која је по својој вредности негде између дугог узлазног и дугог силазног акцента. У нашим белешкама, сачињеним у време прикупљања материјала, уз такве примере и стоји напомена да чујемо „нешто између”. ${ }^{10}$ Ову акценатску појаву није лако уочити јер изискује нарочите околности да би се

${ }^{9}$ „Тај се акценат по својим особинама налази негде између^и/. Очигледно и за њега важи оно што је констатовано за у Славонији: од`он се разликује узлазним (или бар равним) тоном на акцентованом вокалу, а од/ниским тоном на следећем слогу. Слушни утисак далекосежно варира приближавајући се час једном час другом од тих суседа у систему" (Ивић 1994: 245). УП. ПЕтровић - Гудурит 2008: 426; РАдић 2010: 44, 49; 1990: 9.

${ }^{10}$ Примедбе овога типа почели смо давати у каснијој фази, када смо већ преслушали знатан број трака. Та чињеница, претпостављамо, може ићи у прилог томе да што смо више слушали примере с акутом, односно примере где на месту старог акута бележимо акценатску вредност која се налази између дугосилазног и дугоузлазног акцента, јасније смо тај специфични акценат чули, тј. препознавали. На самом почетку трагања, припремили смо ухо за препознавање дугоузлазног акцената на месту дугосилазног. Како је време одмицало и наше ухо извесно време слушало ту акценатску вредност на поменутој позицији у речи, постало је осетљивије и способније да дефинише и препозна то што је звучало као „то нешто између”. 
идентификовала у говору, и снимљеном и живом, а пре свега због (врло) ниске фреквенције потврда за акут и, истовремено, знатнијег броја потврда истих облика с дугосилазним акцентом. ${ }^{11}$ Препознавање ове акценатске вредности отежава и чињеница да је узлазност у интонацији једно од основних средстава у експресивизацији говора. На то је још 1909. године скренуо пажњу Александар Белић, запазивши ту црту у говору Цреса (2000: 344). У овом тренутку, сматрамо, довољна је идентификација мелодијске компоненте дугог акцента с акутском интонацијом у позицијама које историјски одговарају неоакуту, мелодије која опонира типичном дугосилазном акценту, очекиваном за четвороакценатски систем којем истраживана област припада. Без посебне анализе за сада се не може коначно прецизирати карактер такве тонске линије која на читавом, доста широком простору не мора бити у свему истоветна.

Ареал који се оцртао и пунктови које смо овом приликом обухватили, претпостављамо, не представљају и крајње тачке где се чувају остаци овог акценатског архаизма. Приликом оцртавања граница, не сме се изгубити из вида чињеница да кладањски крај представља „најистуренију позицију акута у западнијим штокавским областима" (Ивић 1994: 245) (в. Реметић 1982; 2004). Нас, у овом моменту, интересује да ли трагови акута на штокавском терену могу чинити непрекинути ареал од Копаоника до Кладња у правцу север-северозапад, на једној страни, и докле ће се та граница постојања акута померити према северу, на другој страни, односно - које су крајње тачке његовога простирања на северној страни.

Судећи према нашој засад оформљеној мрежи пунктова, ова појава може се очекивати у троуглу између река Дрине, Саве и Колубаре. Као један од главних задатака у будућим истраживањима говора ове простране зоне недвосмислено се намеће праћење напоредног јављања двеју архаичних црта потврђених у досадашњим истраживањима на овом терену - незамењеног јата и трагова дугог акута.

\section{СПИСАК ПУНКТОВА ПО ОБЛАСТИМА}

Jaдар (Тршић, Ступница, Симино Брдо, Бадања, Сипуља), Рађевина (Бела Црква, Липеновић, Шљивова, Ставе, Толисавац, Бастав, Комирић, Равнаја), Подг̄орина (Осладић, село Осечина, Остружањ, Драгодол, Царина), Колубара (Боговађа) и Посавойманава (Зукве) (в. Карту).

11 У дијалекатским текстовима који прате студију Морфолощке особеносӣи г̄овора средње Колубаре, дугоузлазни акценат на позицији неоакута забележен је у примеру: Ја била ма́ла (РАдовАновит 2006: 162). На терену Ваљевске Подгорине истраживач је забележио још неке примере с дугоузлазним акцентом на позицији неоакута: Прӓвйш $\bar{u} u ́$ пӧсиру (РАдовАновић 2014: 342), А ка сам би́ла мла́да, ва̂л је до зѐмље̄ (РАдовАновић 2014: 61), И ӧпе̄ су оेни довѐли кýмa (РАдовАновић 2014: 354), До́ђе̄м ја̂ кӱћи (РАдовАновић 2014: 357). Ови примери, иако с обележеним дугим узлазним акцентом могли би се сматрати потврдама трагова неоакута (истицања курзивом су наша). 


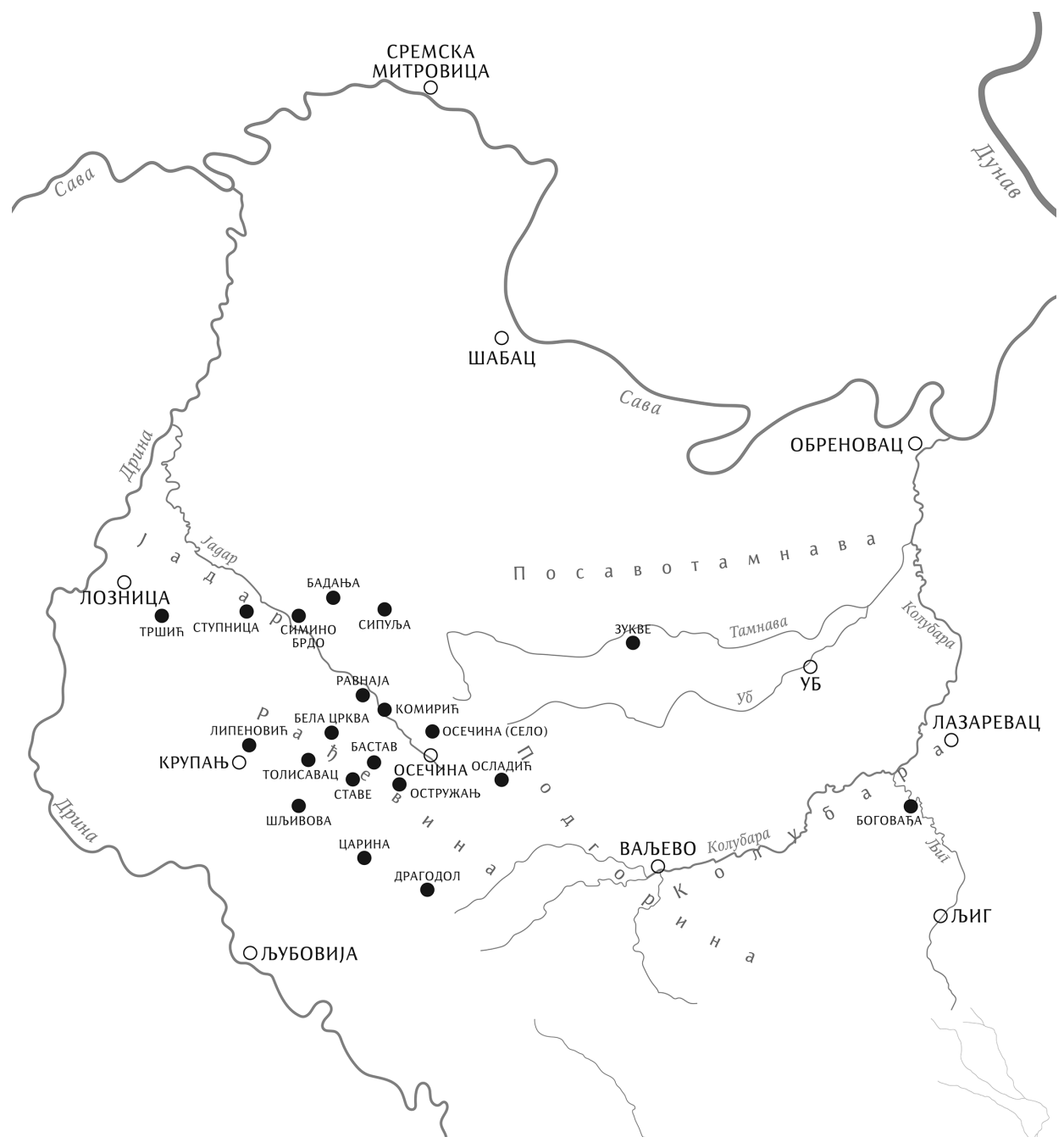

Северозападна Србија с пунктовима у којима су потврђени трагови неоакута

\section{ЦИТИРАНА ЛИТЕРАТУРА}

БЕлић, Александар. Периодизација српскохрватског језика. Јужнословенски филолог̄ XXIII (1958): 3-15.

БЕлић, Александар. Изабрана дела Александра Белића Х. О дијалектиима. Београд: Завод за уџбенике и наставна средства, 2000.

Драгин, Гордана. Неоакут у студеничким говорима. Божо Ћорић и др. (ур.). Србистиички йрилози, Зборник у части йрофесора Славка Вукомановића. Београд: Филолошки факултет, 2005, 89-92.

Ивић, Павле. Неоакут на падинама Копаоника. Зборник Майице срӣске за филолог̄ију и линг̄вистиику XXXVII (1994): 239-246. 
Ивић, Павле. Српски дијалекти и њихова класификација. Зборник Майице срйске за филоло$\bar{z}$ ију и линг̄висииику XLI/2 (1998): 113-132.

Ивић, Павле. Српски дијалекти и њихова класификација II. Зборник Майище срйске за филолог̄ију и линг̄вистиику XLII (1999): 303-354.

Милорадовић, Софија. Косовско-ресавски говори Косова и Метохије. Статус унутар дијалекатске формације, преглед одлика и истражености. Косовско-метиохијски зборник 8. Београд: САНУ, 2019, у штампи.

Николић, М. Берислав. Главније акценатске особине у говору Ваљавске Колубаре. Зборник Майице срйске за филолог̄ију и линг̄вистиику IX (1966): 77-95.

Николик, М. Берислав. Тршићки говор. Срйски дијалекеиолощки зборник XVII (1968): 367-463.

Николић, М. Берислав. Колубарски говор. Срииски дијалекӣолощки зборник XVIII (1969): 1-71.

Петровић, Драгољуб, Снежана Гудурић. Неоакут на северном подножју Рудника. Срето Танасић (ур.). Зборник Инстиитиуйа за срйски језик САНУ I. Београд: Институт за српски језик CAHУ, 2008, 419-428.

Петровић, Драгољуб. Напомене о говору Качера. Зборник Майице срӣске за филолог̄ију и лингвистикку XLII (1999): 383-394.

ПЕтровић, Драгољуб. Трагови неоакута у говорима југозападне Србије. Милета Букумирић

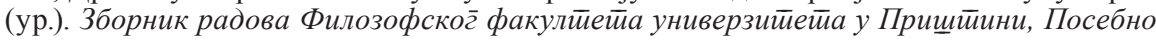
издање йосвећено ироф. др Милосаву Вукићевићу. Косовска Митровица: Филозофски факултет, 2010, 397-402.

ПЕтровић, Мирјана. Основне фонетске особине рађевског села Бела Црква. Прилози ироучавағу језика 36 (2005): 269-292.

РАдић, Првослав. Цртице о говору села Мрче у куршумлијском крају. Срйски дијалекйолощки зборник XXXVI (1990): 1-74.

РАдић, Првослав. Трагом једне Белићеве дијалектолошке екскурзије. О подјастребачким говорима. Срйски језик V (2000): 381-406.

РАдић, Првослав. О говору јагодинског краја. Јудита Планкош (ур.). Животи и дело академика Павла Ивића. Суботица - Нови Сад - Београд: Градска библиотека Суботица, Матица српска, Филозофски факултет у Новом Саду, Народна библиотека Србије, Српска академија наука и уметности, Институт за српски језик САНУ, 2004, 251-271.

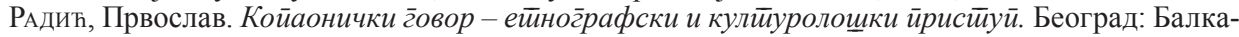
нолошки институт САНУ, 2010.

РАдић, Првослав. О траговима старосрпског акута у говорима Косова и Метохије (Путевима једног научног открића у Срба). Софија Милорадовић (ур.). Косово и Мейохија у ичивилизаиијским йоковима І. Косовска Митровица - Београд: Филозофски факултет Универзитета у Приштини - Завод за уџбенике, 2010а, 229-242.

РАдовановић, Драгана. Морфолошке особености говора средње Колубаре. Срйски дијалекӣоломки зборник LIII (2006): 189-374.

РАдовановић, Драгана. Говор Ваљевске Подгорине. Срйски дијалекйоломки зборник LXI (2014): 7-366.

РАдовАновић, Драгана, Жарко БошњАковић. Степен испитаности народних говора на подручју шумадијско-војвођанског дијалекта. Јужнословенски филолог̄ LXV (2009): 229-265.

РАдоичић, Ивана. Фонолошки опис говора лепосавићке околине. Прилози ироучаваюу језика 27 (1996): 32-52.

Реметић, Слободан. О незамењеном јату и икавизмима у говорима северозападне Србије. Срйски дијалектиолощки зборник XXVII (1981): 7-105.

РемЕтић, Слободан. Питање икавизама шумадијско-војвођанског дијалекта у свјетлу потврде

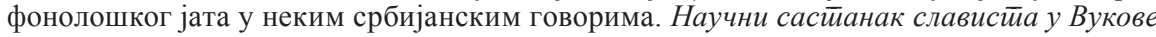
дане 10/1 (1981a): 103-108.

Реметић, Слободан. О још једном незапаженом екавско-јекавском босанском говору. Научни састианак слависӣа у Вукове дане 11/2 (1982): 181-186.

Реметић, Слободан. О шесточланом прозодијском систему у говору Кладња и околине. Јудита Планкош (ур.). Живой и дело академика Павла Ивића. Суботица - Нови Сад - Београд: Градска библиотека Суботица, Матица српска, Филозофски факултет у Новом Саду, Народна библиотека Србије, Српска академија наука и уметности, Институт за српски језик САНУ, 2004, 651-660.

САвич, Виктор. Звуковое значение надстрочных знаков в Святостефанском хрисовуле (1317-1318). Славянское и балканское языкознание, Палеославистика 2 (2019): 315-348. 
PECO, Asim. Tragovi metatonijskog akuta u srpskohrvatskoj štokavštini. Iz jezičke teorije i prakse. Beograd: Naučna knjiga, 1987, 252-257.

Remetić, Slobodan, Ivić, Pavle. Osladić (OLA 62). Pavle Ivić (ur.). Fonološki opisi srpskohrvatskih/ hrvatskosrpskih, slovenačkih i makedonskih govora obuhvaćenih Opšteslovenskim lingvističkim atlasom. Sarajevo: Akademija nauka i umjetnosti Bosne i Hercegovine, 1981, 477-484.

Mirjana Petrović-Savić

\section{TRACES OF THE NEOACUTE ACCENT IN THE SPEECHES OF NORTHWESTERN SERBIA}

Sum mary

The paper presents the preliminary results of our research into the existence of the neoacute accent in the territory of northwestern Serbia (Jadar, Rađevina, Podgorina, Kolubara and Posavotamnava). The available linguistic materials show that this old accent is found in monosyllabic words

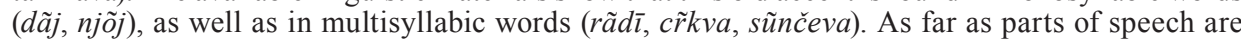
concerned, it can be found in verbs, nouns, pronouns, adjectives and adverbs.

The examples presented in this paper lead to the conclusion that the neoacute accent can be found in northwestern Serbia, at least in traces. The identified examples presented in this paper confirm its existence and serve as the evidence that it in the observed area, it has not become identical with the long falling accent.

Институт за српски језик САНУ

Кнез Михаилова 36, 11000 Београд, Србија

(Примљено: 31. марта 2020;

Mirjana.Petrovic@isj.sanu.ac.rs

прихваћено: 5. јуна 2020) 